foreign countries in a large Russian city]. Observatoriya kul'tury [Observatory of Culture], № 1 (2014), pp. 43-47.

8. R. K. Tangalycheva. Problemy akkul'turatsii vremennyh migrantov v krupnom possiiskom gorode: kul'turnye razlichiya $\mathrm{v}$ neverbal'noy kommunicatcii [Problems of acculturation of temporary migrants in a large Russian city: cultural differences in non-verbal communication]. Sotsiologitcheskiy zhurnal [Sociological journal], № 3 (2011), pp. 24-39.

9. F. R. Kluckhohn, F. L. Strodtbeck. Variations in Value Orientations.: Row and Peterson, New York (1960).

10. R. Inglhart, K. Vel'tsel'. Modernizatsiya, kul'turnye izmereniya i democratiya: Posledovatel'nost' chelovecheskogo razvitiya [Modernization, Cultural Change and Democracy: Sequencing Human Development]. Novie izdatel'stvo, Moscow (2011).

11. E. T. Hall. The Silent Language. Doubleday, Garden City, N. Y. (1959).

12. G. Hofstede. Culture and Organization: Software of the Mind. McGrow-Hill, London (1991).

13. G. Hofstede. Culture's Consequences: Comparing Values, Behaviors, Institutions, and Organizations Across Nations, 2nd ed. Sage Publications, CA (2001).

14. R. D. Luis. Delovye kul'tury v mezhdunarodnom biznese. Ot stolknoveniya $\mathrm{k}$ vzaimoponimaniyu [Business cultures in international business. From collision to mutual understanding]. Delo, Moscow (2001).

DOI 10.15826/B978-5-7996-3081-2.17

\title{
Laboratory of Linguistic Meanings Within Communication Trends of the Post-Literacy Era
}

\author{
Ivanyan Elena', Gurova Irina² \\ 1 Samara State University of Social Sciences and Education, Samara, Russia \\ ${ }^{2}$ Samara State University of Social Sciences and Education, Samara, Russia \\ Corresponding author: Ivanyan Elena, ivanyan@pgsga.ru
}

Abstract. The article investigates the problem of forming polyliteracy within the framework of the University Laboratory of Linguistic Meanings. The choice of activities is justified: ontolinguistics; Russian as a foreign language; linguoecol- 
ogy; creative linguistics. The paper describes the following forms of work: virtual Museum "Samara linguistic school"; linguistic club "Language and the world"; international recitation competition; online conferences with leading linguists; interactive classes; regional interuniversity linguistic competition. The article presents the results of a pedagogical experiment undertaken at Samara State University of Social Sciences and Education.

Keywords: cultural identity, language teaching, monolingual environment, non-formal learning, polylingual children

\section{Introduction}

Literacy is an increasingly urgent issue in the Russian scientific community today. It should be noted that the concept of literacy, that has been recently interpreted as "the ability to read and write", has expanded its meaning: now it is studied as "functional", "multiple", "multimodal", "informational", "media", "computer", "visual", "audiovisual" and "network" literacy. In the context of digitalization of all spheres of human life, the variability of the modalities of transmission and reception of information, the transformation of traditional methods and forms of work with students in higher educational institutions is natural; the emergence of new educational technologies is justified. The purpose of this study is to summarize the experience of the Higher Education Laboratory of Linguistic Meanings in terms of communication trends of the post-literacy epoch - the formation of students polyliteracy.

\section{Studied material}

The article analyzes four sections (ontolinguistics, Russian as a foreign language, linguistic ecology, linguistics of creativity) and six forms of work (international recitation contest, linguistic club "Language and the World", virtual museum "Samara Linguistic School”, Online conferences with leading specialists in linguistics, interactive classes, and the regional interuniversity linguistic contest). Laboratories of linguistic meanings, as well as participants activities in the educational process in the aspect of the polyliteracy formation among students.

\section{Research methodology and methods}

The methodological basis for the study was the post-literacy theory developed by M. Yu. Gudova [Gudova, 2015; 2019], considered "a distinguishing modern culture of coexistence and systematic (interrelated) functioning of all 
forms of literacy formed in the history of culture, based on computer technologies and mass media" [Gudova, 2015, 28]. In carrying out this study, a complex of complementary methods was used: 1) theoretical methods (analysis, synthesis, description, generalization); 2) empirical method (pedagogical experiment).

The study was conducted in several stages.

At the first stage (2013-2015) the works on cultural studies, linguistic, linguo-methodical and pedagogical literature were studied. The creation of the Virtual Museum "Samara Linguistic School” started. An experiment, which revealed the level of polyliteracy of students, was carried out in Samara State University of Social Sciences and Education.

The second stage (2015-2018) was dedicated to the development of experiential learning.

At the third stage (2018-2019) the experimental training continued and the results of the control experiment were analyzed.

\section{The conceptual framework of the study}

In this study, we use the concepts of "multimodality", "multimodal text", "creolized text", "multiculturalism", "polyliteracy". The meaning content is as follows.

The terms "multimodality" ("polymodality") and "multimodal" are used in scientific works on cognitology, psychology, neurophysiology, linguistics, etc., for example, Sizikova, 2019; Blinova, 2019a; Bhaskar et al., 2017; Baldry, Thibault, 2010; Anderson, Kachorsky, 2019; ÓHalloran, Smith, 2012. Multimodal interpretive practices are studied in Lewkowich, 2019.

It is important to state that multimodality describes communication practice in terms of various resources or modes, used to create messages: text, auditory, visual, spatial messages, etc. The set of these modes determines how multimodality affects various rhetorical situations, the ability to guide the audience's perception of an idea or concept [Kress, 2010; Lutkewitte, 2013; Murray, 2013].

Scientists claim that multimodal text production is common in various cultures and societies; it has become a central part of many people's daily lives [Mills, Unsworth, 2018] and an important aspect of educational practices [Milenkova et al., 2018; Stanojević et al., 2018; Kuzmanović, 2019; Lewkowich, 2019].

The literature analysis has shown that the concept of "multimodal text" is interpreted ambiguously. A. A. Kibrik considers the text, in the perception 
of which several channels are involved (primarily the visual and auditory ones) to be multimodal text [Kibrik, 2010, 135]. From the point of view of E. D. Nekrasova, it is necessary to distinguish between multimodal and polycode text containing different semiotic visual (verbal and iconic) signs. The scientist refers to polycode texts as newspaper discourse, Internet communication and postcard texts, etc. A polycode text can be monomodal if it is perceived only with the help of a visual analyzer [Nekrasova, 2014, 45]. O. A. Blinova considers a magazine cover to be a sample of a multimodal text [Blinova, 2019b]. L. N. Glebova and Yu. A. Platonova write about the requirements for a multimodal educational text [Glebova, Platonova, 2016].

Yu. A. Sorokin and T. F. Tarasov define creolized texts as the ones "the texture of which consists of two inhomogeneous parts: verbal (language / speech) and non-verbal (belonging to other sign systems)" [Sorokin, Tarasov, 1990, 180].

In this article, a multimodal text is understood as a text that is a complex of verbal and visual components. The terms "multimodal text" and "creolized text" are used synonymously.

We consider multiculturalism as a personal quality of a person, acting as the basis for positive intercultural relations in society [Makazhanova et al., 2019]. V. L. Kraynik states: "Educational activities are designed to attract students to the diversity of culture, to contribute to the formation of a "multicultural" person" [Kraynik, 2015, 53].

Polyliteracy is defined as the ability to analyze and create a multimodal text.

\section{Laboratory of linguistic Meanings (LLM): General questions}

For 5 years (2015-2020) the research "Laboratory of Linguistic Meanings" (hereinafter - LLM), headed by Doctor of Philological Sciences, Professor Elena Pavlovna Ivanyan and PhD of Philological Sciences, Associate Professor Irina Vladimirovna Gurova [Gonnova et al., 2019; Ivanyan et al., 2020], has been functioning at Samara State University of Social Sciences and Education. The objectives of LLM are to present domestic and foreign scientific linguistic heritage to students of different levels of education, creating conditions for their intellectual development and self-realization in the field of language research, increasing the level of polyliteracy. The spheres of LLM interests include ontolinguistics, Russian as a foreign language, linguistic ecology, linguistics of creativity and are connected with the educational 
profiles at the philological faculty and the faculty of primary education at the university (bachelor and master degrees), as well as by the integration of scientific interests of the teaching staff and students. Let us briefly characterize the mentioned spheres of scientific interest.

Ontolinguistics (linguistics of children's speech) is one of the modern anthropocentric sciences. The object of the study is child speech activity and the subject is children's native language learning [Zeitlin, 2008, 45]. This is of particular importance at the faculty of primary education which is carrying out the training of teachers of preschool educational organizations and the primary school teachers.

The studies in the field of Russian as a foreign language allow to provide readiness of the future teachers training of inophone children in the polyethnic environment. Thus, an integrative (multidisciplinary) approach to the study of child speech activity and its management is carried out.

Much is done in the sphere of linguoecology. The subject of linguoecology is the problems of Russian speech, speech degradation and factors that help eliminate degradation, speech rehabilitation [Ivanyan, 2017].

Creativity linguistics is a young branch of Russian science exploring the process and product of homo ludens - a playing person. Linguistic creative is based on the conscious or unconscious violation of the norm and choice of a non-standard language code [Gridina, 2013, 10].

LLM organizes and implements a variety of scientific activities: scientific and methodological seminars, interactive classes, regional interuniversity linguistic competition, international competition recitation, etc. Research on the materials of network and non-network multimodal and polylingual texts are carried out within the framework of the linguistic club "Language and World", and also on the platform of the virtual museum "Samara Linguistic School”. [Virtual Museum, URL; Ivanyan, Belkina, 2013].

Let's consider some forms of LLM's work: 1) international competition of recitation; 2) linguistic club "Language and World"; 3) virtual museum "Samara Linguistic School”; 4) online conferences with leading specialists in linguistics; 5) interactive classes; 6) regional interuniversity linguistic competition.

\section{International recitation competition}

The purpose of the international competition is to reveal the potential of student youth, popularize and support the study of Russian culture and language, civilizational and spiritual values of the Russian people. Students 
representing several higher education institutions from different countries take part in the competition.

The competition represents a unique communication space for realization of hybrid types and forms of creativity. Participants need to create a video with declamation of the text proposed by the event organizers. The language of the declamation is Russian. Video can be recorded by any technical means; subtitles, voice-over, video special effects, animation, music are acceptable. The recording should not exceed three minutes. It is possible to choose one of the forms of participation: individual or team.

The authors are to post their creative work on the video hosting YouTube, indicating the name of the contest, the name of the reciter and the citizenship. After posting the video on YouTube, the contestant sends the jury members an electronic link to the multimedia product. The competition winners and prizewinners will be determined in three categories: "The most technical reciter", "The most artistic reciter", "The most original reciter".

The competition organizers select the texts for the declaration in accordance with the following principles:

1. Seasonal and thematic principle. Thus, in winter 2018 there was the New Year theme. T. Tolstaya's essay "An Empty Day" was proposed for the recitation [Tolstaya, 2010]. In autumn 2019 the theme "The colors of autumn from the linguistic perspective" was reflected in the work of K. Paustovsky "Dictionary of native nature" [Paustovsky, URL].

2. Axiological principle. This principle is justified by the international competition objectives: preservation of spiritual heritage, study of basic national values of the Russian people. Consequently, the declared text should contain a variety of linguistic, cultural and historical information.

3. The principle of multi-modality. A work for declamation provides the contestant with an opportunity to communicate with the audience on the basis of audio, spatial, visual and other modes.

LLM managers provide the word stress and a linguistic commentary in the recitation text for the inophone participants.

The creative works analysis of the contestants from different countries has shown that the problem of student polyliteracy is solved with the help of video clip creation in the optimal form. Students play out interesting videos according to the given text that illustrate the advantages of the proposed literary text. 


\section{Linguistic club "Language and the world"}

The linguistic club "Language and the world" was organized at the faculty of Philology of Samara State University of Social Sciences and Education in 1998. For more than 20 years, the club has been headed by Professor E. P. Ivanyan. The LLM scientific and methodological portfolio expands the experience of using online services of Samara State University of Social Sciences and Education electronic information and educational environment when interacting with students (materials of Electronic Document Management on the websites of faculties and departments (educational disciplines), university e-mail services, calendars, planners, mailing lists, collaboration with documents in OneDrive network storage, Yammer corporate social network, video hosting based on Stream, etc.).

In the corporate social network Yammer there is a group called "Linguistic club "Language and world". The priority activity of the group members was linguistic problem solving, including the linguistic analysis of multimodal texts (for example, demotivators). A demotivator (demotivation poster) is a two-part text that consists of a picture in a black frame and a slogan commenting on it. A multimodal text of this type corresponds to one of the four spheres of human life: social, political, economic, or spiritual. O. N. Lutovinova identifies autosemantic and synsemantic relationships between the verbal and iconic parts of the demotivator. The scientist points out the fact that autosemantic relations are typical for texts in which the iconic component is not necessary for the correct understanding of the verbal component. Synsemantic relations are an attribute of a text in which the verbal part cannot be correctly understood without an iconic component [Lutovinova, 2016]. The subject of student analysis is the language game techniques in demotivators. Linguistic problems based on the material of the German group "Rammstein" video developing student multiculturalism is of particular interest.

It should be noted that the tasks posted in the Yammer group "Linguistic club "Language and the world" contribute to solving the problem of student polyliteracy both in actual time (it is suggested to solve a linguistic problem before a certain date; decisions are commented on by the members of the linguistic club, and the teacher sums up the results, correlating the results with the criteria of completeness, solution accuracy, the speed of the host response, originality) and in individual educational study. 
The results of research activities of teachers and students on the analysis of multimodal texts are presented in publications [Ivanyan, Anikin, 2019; Anikin, Mikhailova, 2019; Gurova, 2020].

\section{Virtual Museum "Samara linguistic school"}

The Virtual Museum "Samara linguistic school" was created with the financial support of the Russian Humanitarian Science Foundation as part of the research project of the regional competition "Volga lands in the history and culture of Russia" 2013 - Samara region "Design of a regional model of virtual museums of scientific schools (based on the material of Samara linguistic school)" project № 35/2013 - Russian Humanitarian Science Foundation. Registration NIOKR № CITiS 01201364148 (NIOKR- scientific research, development and technological work, CITiS - Center for information technologies and systems of executive authorities). The Museum director is Professor E. P. Ivanyan [Virtual Museum, URL].

The LLM participants are developing Virtual Museum projects:

1) Creating videos about Samara linguistic school scientists:

a) a film about one of the founders of Samara linguistic school - doctor of Philology, Professor E. S. Skoblikova was created at the initiative of the Director of the Virtual Museum, with the support of the Department of Russian language, culture of speech and teaching methods and the Dean of the Philology faculty of Samara State University of Social Sciences and Education;

b) the students made movies about E. P. Pronina, M.N. Veserova and L. K. Skorokhod.

Actually, the movie-making is the research, the results of which are reflected in regional scientific student conferences (2018-2020) and all-Russian Universiade in the Russian language (December 2018 - January 2019). Students prepared a video of Professor E. P. Pronina, took the 2nd place and took part in the final stage of the Universiade (January 2019).

2) Work with personalia: create audio recordings, drawings (clicking to see the awards scientists of Samara school of linguistics).

It should be noted that since the exhibits of Samara linguistic school Museum are virtual objects, the achievements of LLM participants become the actual property of the entire Samara region. The student polyliteracy level increases when studying the Virtual Museum exhibits (audio recordings, photo galleries, etc.). Samara is a multi-ethnic region, where Tatars, Mordvins, and Chuvashes have been living together with Russians for centuries. Materials within the sci- 
entific research interests of Professor A.N. Gvozdev allow developing the multiculturalism of students, as they contain information on the scientist's research of the Mordovian language when he lived and worked in Penza.

\section{Online conferences with prominent linguists}

Online conferences are held at least once a year. The participant contingent consists of master's degree students of the academic master's program "Russian language in school compulsory and higher education". Bachelors are the winners of the contest of linguistic problems. The format of online conferences is carried out in EOS Samara State University of Social Sciences and Education. The forum has video-recording and 1.5-2 months before the start of the conference, information about this scientific event is posted on the social networks of Samara State University of Social Sciences and Education, indicating the name of the leading scientist and the scientific interests while the conference program is proposed.

Thanks to the online communication format, students get the opportunity to interact with a leading specialist-linguist, ask questions, pose problems and answer urgent tasks formulated by the scientist. The online conferences were attended by doctor of Philology, Professor of the Kazakh national pedagogical University named after Abay A. K. Zhumabekova (Kazakhstan); doctor of pedagogical Sciences, Professor from Serbia (Novy Sad city) M. Knezhevich; PhD of Philology, associate Professor of the University of Lodz A. Piasecka (Poland). Videos of online conferences and news notes about each scientific event are posted on the website of Samara State University of Social Sciences and Education. Information about the online conference 2019 is available on the social network Facebook [Samoilova, $\mathrm{URL}$ ]. Learning Russian as a foreign language contributes to the formation of polyliteracy and the multiculturalism of students: bachelors and master's degree students become acquainted with Serbian, Polish or Kazakh linguocultures (on the basis of language material, ethnically marked phraseological units, historical and etymological comments of leading scientists in Europe and Asia) at online conferences.

\section{Interactive studies}

Interactive studies include work with multimodal texts for the following disciplines: "Pedagogical Rhetoric" (Faculty of Philology and Faculty of Primary Education), "Fundamentals of Eloquence" (Faculty of Philolo- 
gy), "Linguistic Foundations of Preschool Children Speech Development" (Faculty of Primary Education), "Russian Language" (Faculty of Primary Education), "Semiotics of Political Discourse" (Faculty of Philology) for bachelor's and the discipline "Speech" in the master's degrees training course of "Pedagogical Education" (Faculty of Philology and the Faculty of Primary Education), "Actual problems of the ecology of the Russian language in specialized education" (Faculty of Philology). For example, the studies on the applied aspects of linguistics include (disciplines: "Pedagogical rhetoric", "Fundamentals of eloquence" "Actual problems of the ecology of the Russian language in specialized education") the tasks to analyze multimodal texts of TV programs of N. Mikhalkov "Besogon" and D. Kiselyov "weekly news" to identify rhetorical techniques, successes and shortcomings. The students prepare a mini-study, then, in an interactive practical lesson, they offer the group to watch small fragments from the mentioned TV programs lasting 30-60 seconds in order to determine the method of elocution, identify a defect, give a linguo-ecological characteristic of this fragment, etc.

In an interactive lesson on the discipline "Fundamentals of Eloquence", students are invited to study materials from Internet sources about the Watergate scandal 1972-1974 and prepare a polymodal text on one of the topics:

1. The speech of President R. Nixon' supporter at the rally.

2. The campaign statement by a member of the US Democratic Party before voters after the Watergate scandal.

3. TV messages by President R. Nixon to the American people.

4. "Watergates of the XXI century": speech of the TV program "Besogon" host

5. "Watergate as an example of a simulacrum": presentation at a scientific conference.

6. Honorable speech for the journalists who wrote about Watergate in the 1970 s at the Press Day event.

7. Is the element- zеŭm (gate) necessary for the Russian language: TV debates.

During the classes of the discipline "Semiotics of Political Discourse" students were asked to give at least 3 arguments to substantiate their position on the question: WATERGATE: representation or simulation? reality or phantom denotation? Information about the Watergate scandal published by the RIA Novosti news agency was offered as a study material as well as an excerpt from the book by J. Baudrillard "Simulacra and Simulation" and a transcript 
of the conversation between the political observer E. Tolstykh and the head of the Experimental Creative Center, political scientist S. Kurginyan.

Thus, working with multimodal texts in interactive university classes is a creative practice developing students polyliteracy which is relevant in the second decade of the XXI century.

\section{Regional interuniversity linguistic competition}

The regional interuniversity linguistic competition is held once a year in accordance with the Regulations on the competition approved by the Academic Council of Samara State University of Social Sciences and Education. The purpose of the competition is to form student polyliteracy, develop their multiculturalism; students study domestic and foreign scientific linguistic heritage, they have an opportunity to understand and analyze the possibilities of theoretical and practical application.

The competition includes several tasks. The first task includes mastering, and public presentation of, one of the methods of linguistic analysis of the text (linguosemiotic, linguopoetic, linguo-methodological or from the standpoint of linguistic comparative studies (the team choice)).

Linguosemiotic analysis involves the study of the text as a system of signs. In this case, the semantics, syntagmatics and pragmatics of signs become the subject of the contestants' research.

The task of the linguopoetic analysis of the text is to consider the relationship between the verbal and speech structure and the compositional and artistic organization of the work in order to understand the aesthetic impact.

The purpose of the linguo-methodical analysis is to identify the peculiarities of the use of linguistic means by the author of the text, their role in expressing the figurative meaning of the work, as well as in the choice of forms and methodological methods of working with the literary text, among which: methods of semantization and interpretation; stylistic experiment; techniques for visualizing an associative background; verbal and graphic drawing; composing "mood palette" of the hero and the author; creation of a movie script, video clip; ballet design; compilation of a dictionary of visual and expressive means; expressive reading; dramatization, etc. Thus, linguo-methodical analysis is a delayed text reading under a "linguistic microscope" [Shansky, 1986] for the qualification of linguistic phenomena, assessment of the author's word usage and simultaneous methodological commentary. 
Taking into account the interaction of the comparative-historical, comparative-typological and comparative- correlate methods of linguistic comparative studies, the students analyze the texts of Russian and English discourses, various versions of translation of poetic works. This type of activity contributes to the development of the multiculturalism of students.

Presentation is evaluated according to the following criteria:

1) the material corresponds to the proposed topic;

2) the main provisions of the chosen approach to the analysis of linguistic phenomena are noted;

3) knowing of the works of domestic and foreign scientists in the framework of this aspect of the analysis;

4) laconic presentation of information;

5) single style of presentation design, an adequate choice of colors, competent placement of information objects on slides;

6) various types of objects on presentation slides (diagrams, diagrams, drawings, video and audio materials, etc.).

The second competition task is to analyze the text proposed by the organizers in various methodological aspects. The jury evaluates the multimodal text prepared by the participating teams in accordance with the following criteria:

1) the analysis of the text was carried out within the framework of the specified aspect;

2) the analysis of the text was carried out in accordance with the proposed scheme (goal, methods of analysis, conclusions);

3) depth of analysis;

4) original interpretation of the text;

5) verbal and non-verbal components of the created multimodal text form a single (integral) information space;

6) competent speech, absence of grammatical, stylistic and other errors.

The third task is a linguistic question-riddle for the audience to check the formation of the contestants' ability to present linguistic information in a non-standard form.

The fourth task, associated with the analysis of linguistic phenomena presented in various genres of Internet communication and performances, reveals research skills.

In the individual championship, the participants of the competition answer the questions of the quiz: in 2018 it was the monograph by E. V. Du- 
shechkina "Russian Christmas tree: history, mythology, literature" [Dushechkina, 2002], in 2019 it was the monograph by A. P. Vasilevich, S. N. Kuznetsova and S. S. Mishchenko "Color and color names in Russian" [Vasilevich et al., 2005].

The organizers of the annual regional interuniversity linguistic competition underline the effectiveness of the scientific events, the expansion of the number of participants (in 2018 - four teams from two universities; in 2019 - five teams representing three higher educational institutions of Samara and the Samara region).

\section{Results and discussions}

For 5 years (2015-2019), a pedagogical experiment was carried out at Samara State University of Social Sciences and Education. The experiment participants were 50 students taking part in the work of the LLM. At the ascertaining stage of the experiment (October 2015), the level of student polyliteracy was established. The evaluation criteria were: 1 ) the ability to analyze multimodal text from given positions; 2 ) the ability to create a multimodal linguistic text.

Tasks:

1. Analyze the proposed multimodal text: present a version of its interpretation and decoding of meanings transmitted by a complex of verbal and non-verbal methods; identify rhetorical techniques, communicative successes and failures; qualify the techniques of the language game; define the interaction of the verbal and visual parts of the creolized text based on the behavior of grapho-derivatives and foreign language analytes in the proposed text; give a linguoecological characterization of the text.

2. Create a multimodal linguistic text, taking into account the multicultural nature of the audience (genre, type, form of the text - at the choice of the student).

The levels of student polyliteracy were identified in accordance with the following indicators.

High level: the interpretation of the proposed multimodal text and the decoding of the meanings transmitted by a complex of verbal and non-verbal methods were competently carried out; revealed rhetorical techniques, communicative successes and failures; the techniques of the language game are correctly qualified; the interaction of the verbal and visual parts of the creolized text is determined on the basis of the behavior of grapho-derivatives and 
foreign language analytes in the proposed text; a meaningful linguoecological characteristic of the text is given; verbal, visual and auditory components of the created multimodal linguistic text form a single (integral) information space, taking into account the multicultural nature of the audience.

Intermediate level: no more than two mistakes were made when interpreting the proposed multimodal text and decoding the meanings transmitted by a complex of verbal and non-verbal methods; revealed most of the rhetorical techniques, communicative successes and failures; no more than two mistakes were made when qualifying the techniques of the language game; the interaction of the verbal and visual parts of the creolized text based on the behavior of grapho-derivatives and foreign-language analytes in the proposed text is described fragmentarily; the linguo-ecological characterization of the text is formal; the created text uses several modalities of translation of linguistic meanings, the multicultural nature of the audience is taken into account.

Low level: more than two mistakes were made when interpreting the proposed multimodal text and decoding the meanings transmitted by a complex of verbal and non-verbal ways; most of the rhetorical techniques, communicative successes and failures have not been identified; more than two mistakes were made when qualifying the techniques of the language game; the interaction of the verbal and visual parts of the creolized text based on the behavior of grapho-derivatives and foreign-language analytes in the proposed text has not been established; linguoecological characteristics of the text have not been produced; the created text does not involve several modalities of translation of linguistic meanings, the multicultural nature of the audience is not taken into account.

The results of the ascertaining stage of the pedagogical experiment were as follows: a high level of polyliteracy was revealed among $10 \%$ of students (5 students), the average level is $40 \%$ (20 students) and the low level is $50 \%$ (25 students). Thus, the low polyliteracy level prevailed.

At the formative stage of the experiment, a set of scientific and educational activities described above were implemented.

Let us present the results of the control stage of the experiment (May 2019): a high level of polyliteracy was found among $40 \%$ of students (20 students), the average level is $50 \%$ (25 students) and the low level is $10 \%$ of students (5 students). The average polyliteracy level dominated, while the number of students with a high polyliteracy level increased significantly (by $30 \%$ ). 


\section{Conclusions}

Generalization of the work experience of the Higher Education Laboratory of Linguistic Meanings allows drawing a conclusion concerning the effectiveness of the chosen directions, forms and activities in the aspect of the formation of polyliteracy and the development of students' creative abilities.

\section{Conflict of Interest}

The authors have no conflict of interest to declare.

\section{Acknowledgment}

This work was supported by the Russian Humanities Research Foundation grant for the regional research project "Volga region in the Russian History and Culture" 2013 - Samara Region "Designing a regional model of research school virtual museums (based on the research data of Samara Linguistic School)" Project № 35/2013 - RHRF. NIOKR Registration № CITiS 01201364148).

\section{References:}

1. M. Y. Gudova. Chtenie v epohu postgramotnosti: kul'turologicheskij analiz [Reading in the era of post-literacy: a cultural analysis]. Ekaterinburg (2015).

2. M. Y. Gudova. Koncepciya postgramotnosti kak teoretiko-metodologicheskoe osnovanie ponimaniya chteniya Pyatyj mezhdunarodnyj intellektual'nyj "Chtenie na evrazijskom perekrestke" [The concept of post-literacy as a theoretical and methodological basis for understanding reading Fifth International Intellectual Forum "Reading at the Eurasian Crossroads"] Chelyabinsk State Institute of Culture, Chelyabinsk (2019), pp. 22-30.

3. T.E. Sizikova. Vliyanie polimodal'nosti refleksii na samoorganizaciyu lichnosti [Influence of polymodality of reflection on self-organization of personality]. Science for Education Today, No. 1 (2019), pp. 57-75.

4. O. A. Blinova. Mul'timodal'nost' v setevom politicheskom diskurse: internet-memy o nezavisimosti Shotlandii [Multimodality in Networked Political Discourse: Internet Memes on Scotland independence] Nauchnyj dialog, № 10 (2019a), pp. 79-93.

5. S. Bhaskar, M. Köper, S. Schulte Im Walde, D. Frassinelli. Exploring Multi-Modal Text + Image Models to Distinguish between Abstract and Concrete Nouns. (2017).

6. A. Baldry \& P. J. Thibault. Multimodal transcription and text analysis. (2010). 
7. Assessing students' multimodal compositions: an analysis of the literature Kate T. Anderson Division of Educational Leadership and Innovation, Arizona State University, Tempe, Arizona, USA, and Dani Kachorsky Department of Curriculum, Instruction and Learning Sciences, Texas A\&M University. Corpus Christi, Texas, USA (2019).

8. K. O’Halloran, B. Smith. Multimodal Text Analysis. (2012), 10.1002 / 9781405198431.wbeal0817.

9. D. Lewkowich. Assuming a hybrid logic of reading: comics, psychoanalysis, and the multimodal promise of visual response. Department of Secondary Education, University of Alberta, Edmonton, Alberta, Canada (2019).

10. G. Kress. Multimodality: A Social Semiotic Approach to Contemporary Communication. Routledge, New York, 2010.

11. C. Lutkewitte. Multimodal Composition: A Critical Sourcebook. Bedford / St. Martin's, Boston (2013).

12. J. Murray. Composing Multimodality. Multimodal Composition: A Critical Sourcebook / Lutkewitte, Claire. Bedford / St. Martin's, Boston (2013).

13. K. Mills, L. Unsworth. Multimodal literacy. Curriculum and Pedagogy, Technology and Education, Languages and Literacies Online (2018), 10.1093/acrefore/9780190264093.013.232

14. M. Kuzmanović, J. Andjelković Labrović, A. Nikodijević. Designing e-learning environment based on student preferences: conjoint analysis approach. International Journal of Cognitive Research in Science, Engineering and Education (IJCRSEE), No. 7 (3) (2019), pp. 37-47.

15. V. Milenkova, D. Peicheva, M. Marinov. Towards defining media socialization as a basis for digital society. International Journal of Cognitive Research in Science, Engineering and Education (IJCRSEE), No. 6 (2) (2018), pp. 21-32.

16. D. Stanojević, D. Cenić, S. Cenić. Application of computers in modernization of teaching science. International Journal of Cognitive Research in Science, Engineering and Education (IJCRSEE), No. 6 (2) (2018), pp. 89-106.

17. A. Kibrik. A Multimodal linguistics Cognitive research IV. IP RAS, Moscow (2010), pp. 134-152.

18. E. D. Nekrasova. K voprosu o vospriyatii polimodal'nyh tekstov [On the question of the perception of polymodal texts]. Vestnik Tomskogo gosudarstvennogo universiteta [Bulletin of the Tomsk State University]. No. 378 (2014), pp. 45-48.

19. O.A. Blinova. Oblozhka zhurnala kak mul'timodal'nyj tekst [Journal cover as a multimodal text]. Nauchnyj dialog [Scientific dialogue], No. 5 (2019b), pp 9-24.

20. L. N. Glebova, Y. A. Platonova. Mul'timodal'nyj obrazovatel'nyj tekst massovyh otkrytyh onlajn-kursov (mook): rekomendacii po vizualizacii kontenta [Mul- 
timodal educational text of massive open online courses (mook): recommendations for content visualization]. Scientific dialogue, No. 10 (58) (2016), pp. 336-348.

21. Y.A. Sorokin, E. F. Tarasov. Kreolizovannye teksty i ih kommunikativnaya funkciya. Optimizaciya rechevogo vozdejstviya [Creolized texts and their communicative function. Optimization of speech impact]. Nauka, Moscow (1990), pp. 181-186.

22. Zh. M. Makazhanova, F. A. Bataeva, A. A. Brataeva, I. A. Mavrina. Osobennosti formirovaniya polikul'turnosti kak lichnostnogo kachestva studentov i osnovy pozitivnyh mezhkul'turnyh vzaimootnoshenij v usloviyah sovremennogo obrazovaniya [Features of the formation of multiculturalism as a personal quality of students and the basis of positive intercultural relations in the conditions of modern education]. Science for Education Today. Vol. 9, No. 4 (2019), pp. 231-246.

23. V.L. Kraynik. Kul'tura uchebnoj deyatel'nosti studentov: sushchnost', definicii, principy formirovaniya [The culture of students' educational activity: essence, definitions, principles of formation]. Vestnik Novosibirskogo gosudarstvennogo pedagogicheskogo universiteta [Bulletin of the Novosibirsk State Pedagogical University], No. 6 (28) (2015), pp. 50-56.

24. N. V. Gonnova, I. V. Gurova, M. G. Sokolova. Laboratoriya lingvisticheskih smyslov (po itogam cikla nauchnyh meropriyatij [Laboratory of linguistic meanings (based on the results of a cycle of scientific events)]. Rusistika bez granic [Russistics without borders], Vol. 3, No. 3 (2019), pp. 103-108.

25. E. P. Ivanyan, N. G. Kochetova, P. S. Ivanova. Laboratoriya lingvisticheskih smyslov: mezhdunarodnye konkursy studencheskoj deklamacii [Laboratory of linguistic meanings: international competitions of student recitation]. Rusistika bez granic [Russistics without border, Vol. 2., No. 2 (2020), pp. 123-127.

26. S. N. Zeitlin. Ontolingvistika kak uchebnaya disciplina [Ontolinguistics as an academic discipline]. Russkij yazyk v shkole [Russian language at school], No. 6 (2008), pp. 45-49.

27. E. P. Ivanyan. Metafory pedagogicheskoj rechi: lingvoekologicheskij aspect. Rational and emotional in Russian [Metaphors of pedagogical speech: linguoecological aspect. Rational and emotional in Russian]. Proceedings of the International Scientific Conference dedicated to the 85th anniversary of the Honored Scientist of the Russian Federation, Honorary Professor of the Moscow State Regional University, Doctor of Philology, Professor Pavel Aleksandrovich Lekant. MGOU, Mosow (2017), pp. 331-333.

28. T. A. Gridina. K istokam verbal'noj kreativnosti: tvorcheskie evristiki detskoj rechi [To the origins of verbal creativity: creative heuristics of children's speech]. Lingvistika kreativa [Linguistics of creativity]: Collective monograph 2nd ed. FGBOU VPO, Ekaterinburg (2013), pp. 5-59. 
29. Virtual Museum: Samara Linguistic School, http://c27463.tmweb.ru.

30. E. P. Ivanyan, Y. A. Belkina. Nauchnaya kommunikaciya kak sposob organizacii i prezentacii regional'noj nauki v virtual'nom prostranstve [Scientific communication as a way of organizing and presenting regional science in virtual space]. Izvestiya Samarskogo nauchnogo centra Rossijskoj akademii nauk [Digest of the Samara Scientific Center of the Russian Academy of Sciences], Vol. 15., No. 2-4 (2013), pp. 857-860.

31. T. N. Tolstaya. Pustoj den' Reka [Empty Reka's day]: collection. Eksmo, Moscow (2010), p. 384

32. K. G. Paustovsky. Dictionary of native nature, https://mybiblioteka.su/474028.html.

33. O. V. Lutovinova. Demotivator kak vid setevogo tvorchestva [Demotivator as a type of network creativity]. Vestnik Volgogradskogo gosudarstvennogo universiteta [Bulletin of the Volgograd State University]. Series 2: Linguistics. Volgograd State University, Volgograd, Vol. 15, No. 3 (2016), pp. 28-36.

34. E. P. Ivanyan, A. A. Anikin. "Ne druzhit' s golovoj": bytovanie frazeologizma v novoj fol'klornoj forme ["Not to be friend with your head": the existence of phraseological units in a new folklore form]. Rational and Emotional in Russian: Proceedings of the International Scientific Conference dedicated to the memory of Professor P. A. Lecant. MGOU, Moscow (2019), pp. 272-277.

35. A. A. Anikin, M. Y. Mikhailova. Komp'yuterno-oposredovannaya kommunikaciya kak novaya ploshchadka dlya yazykovoj igry [Computer-mediated communication as a new platform for a language game]. Lingvistika giperteksta i komp'yuterno-oposredovannoj kommunikacii [Linguistics of hypertext and computer-mediated communication]. Proceedings of the international scientific and practical conference. Samara (2019), pp. 5-11.

36. I. V. Gurova. Lingvisticheskij kreativ v "Zhivom zhurnale" (na primere bloga E. Kasperskogo) [Linguistic creativity in Live Journal (on the example of E. Kaspersky’s blog)]. Ural'skij filologicheskij vestnik. Seriya: Yazyk. Sistema. Lichnost': Lingvistika kreativa [Ural Philological Bulletin. Series: Language. System. Personality: Linguistics of creativity], No. 2 (2020), pp. 127-134.

37. T. Samoilova. Conference Samara — Lodz, Poland, https://www.facebook. com/groups/perfor/permalink/2638769196169481/.

38. N. M. Shansky. Hudozhestvennyj tekst pod lingvisticheskim mikroskopom: kniga dlya vneklassnogo chteniya uchashchihsya 8-10-h klassov srednih shkol [Fiction text under a linguistic microscope: a book for extracurricular reading for students of 8-10 grades of secondary schools]. Education, Moscow (1986). 
39. E. V. Dushechkina. Russkaya yolka: Istoriya. Mifologiya. Literatura [Russian Christmas tree: History. Mythology. Literature]. Norint, Saint Petersburg (2002).

40. A. P. Vasilevich, S. N. Kuznetsova, S. S. Mishchenko. Cvet i nazvaniya cveta $\mathrm{v}$ russkom yazyke [Color and color names in Russian]. KomKniga, Moscow (2005).

DOI 10.15826/B978-5-7996-3081-2.18

\title{
Resolving Structural Ambiguity in Language Processing: A Systematic Review
}

\author{
Darzhinova Liubov \\ The Education University of Hong Kong, N.T., Hong Kong \\ liubov@s.eduhk.hk
}

\begin{abstract}
This paper addresses these research questions: (1) What are the main ideas presented in the published articles (2005-2020) on structural ambiguity resolution in language processing? (2) What are the main venues for unveiling research on structural ambiguity resolution in language processing? For that, a systematic review is performed, which reports on the eight most relevant studies. It is found the investigations into the topic of interest are conducted across multidisciplinary areas and primarily in the European institutions and the US. This research is circulated in journals, which are peer-reviewed and indexed by Scopus, Web of Science, and other databases. The other major finding is that psychophysical tests are more popular in the field, and reasons for that are explained. The polarity of results on syntactic disambiguation leaves room for much to be discovered.
\end{abstract}

Keywords: written language processing, parsers, structural ambiguity resolution, systematic review

\section{Introduction}

Multidisciplinary studies have constantly been tackling the peculiarities of human languages. Those investigations have been repeatedly conducted across genetics, neurology, philosophy, linguistics, and many more research fields. Over the last few decades, there has been a considerable attention 